\title{
継手仕口による納まりのプログ STUDY ON REPRESENTATION ラム言語を用いた記述に関する OF TSUGITE-SHIGUCHI USING 研究 PROGRAMMING LANGUAGE
}

$\begin{array}{ll}\text { 加戸啓太 }-* 1 & \text { 高林弘樹— } * 2 \\ \text { 田中智己—2 } & \text { 平沢岳人 } * 3\end{array}$

キーワード :

伝統木造構法, 継手仕口, デジタルアーカイブ, プログラム言語, 三次元モデル

Keywords:

Traditional wooden building system, Tsugite-shiguchi, Digital archive, Programming language, 3D model

\section{Keita KADO Tomoki TANAKA $*$}

Hiroki TAKABAYASHI $-* 2$

In this study, the authors attempt representation of procedures for tsugite-shiguchi by programming language. Classes for parts which have some joints are considered in aspects from geometry generation and information management. Based on these consideration, the authors programmed tsugite-shiguchi representation system which computes shapes of cutting for joints. Procedures for tsugite-shiguchi are compiled follow steps in this system: determining a joint pattern, calculating homogeneous transformation matrices as attitudes of each parts and its joints, creating shapes which represent subtraction from original lumbers. Detailed 3D model of Himeji castle which created with this system is also shown.

\section{1.はじめに}

著者らは伝統木造建築を対象として、部品一つ一つの形状を表現 する精緻さで三次元モデル化し、デジタルアーカイブとする研究を 継続的に行っている1。精緻な三次元モデルを作成するために、部品 の雛形をオブジェクト記述言語注1により定義し、それを三次元 $\mathrm{CAD}$ 図面上に配置・実体（インスタンス）化し、三次元モデルを作成する 手法をとる。作成した三次元モデルについては、三次元プリンタ等で 部品毎に出力し、スケール模型として組み上げる検証を通してその 整合性を確かめている。

ところで、これまでに行われたデジタルアーカイブ化の取り組み では、アーカイブ化の対象ごとに精緻さの程度にいくつか方針があ る。法華経寺五重塔のデジタルアーカイブ化研究では、五重塔の対称 性、層ごとの繰り返しが強い建築の構成から、ある層において同一呼 称の部品は同じ寸法と見な寸方針をとった。このため三次元モデル 内には同じ形状をもつ部品が数多く存在している。姫路城大天守の アーカイブ化研究においては、部材それぞれについて幅成や継手仕 口での納め方に関する情報が残されていることから、出来るだけそ れらに従って三次元モデル化を行う方針をとった。例えば二層目の 梁の部品では、配置位置（番付）によって幅成や長さ、納め方などの 記録があるため、三次元モデル上でもこれに応じた表現を行う。後者 はより精緻なアーカイブ化であり、幅広い活用を見込むことができ る。一方で、柱梁などの部品では、納まりの種別や個数に起因する形 状のバリエーションが増加し、増加に応じて部品雛形を定義してい くと、部品雛形の総数が著しく増加して管理が難しくなり、合理化で きなくなるという問題がある。納まりを有する部品の効率的かつ合 理的な表現手法が求められる。

以上を背景に、継手仕口での納まりに関する知識をプログラム言
語により記述し、三次元モデル化の際に利用できないかと考えた。本 稿では、納まり部を複数持つ部品の雛形のありようについて考察を 行い、続いて納まりが形成される際の手続きを汎用プログラム言語 である $\mathrm{C} / \mathrm{C}++$ 言語により記述する手法について報告を行う。また、 それを利用した姫路城大天守のアーカイブ化についても報告を行う。

\section{2. 納まりを有する部品の雛形}

伝統木造建築の部品同士の納まりには継手仕口などの技法が用い られ、この構法の特徴の一つとなっている。例えば腰掛け蟻継ぎと呼 ばれる継手は図 1 に示すような作図法で設計され、基本的にはその 形状は部材の幅、成によって決まることがわかる。デジタルアーカイ ブ化研究では、こういった作図法を記述したものを雛形とし、三次元 モデル化に利用している。雛形の記述は、伝統的な設計法をコン ピュータ上で表現したものであり、構法の知識表現の一手法として 有効であると考えている。

さて、こういった納まり方をする部品の表し方を考えた場合、いく つか異なった方法が考えられる。部品雛形での納まりの表現の仕方 や納め方に関する情報の管理といった観点から考察する。

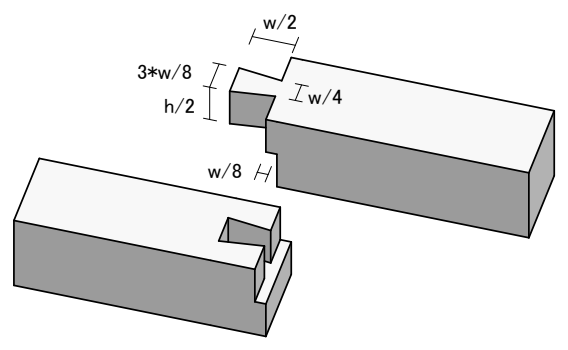

図 1： 腰掛け蟻継ぎの設計

\footnotetext{
立命館大学理工学部 助教

(干 525-8577 滋賀県草津市野路東 1-1-1)

千葉大学大学院工学研究科 博士後期課程

千葉大学大学院工学研究科 准教授
}

\footnotetext{
Assistant Prof., College of Science and Engineering, Ritsumeikan Univ.

Graduate School of Engineering, Chiba Univ.

Assoc. Prof., Graduate School of Engineering, Chiba Univ.
} 


\section{1. 納まり方の記述の仕方}

部材個々の幅成、納まりを表現する精緻さで三次元モデルを作成 しようとすると、部品の形状のバリエーションが増加する。これに対 応する手法として、部品雛形を新たに定義する方法と、部品雛形に公 開変数を追加し部品雛形の柔軟性を高める方法がある。納め方や納 まりの数の異なる部品のバリエーションを考えると、前者は納まり をパラメトリックに扱わない（ノンパラメトリックな）手法、後者は パラメトリックに扱う手法であると整理できる。これらの手法につ いて図 2 に示寸土台のバリエーションを例に考察する。

ノンパラメトリックに扱う手法では、納め方が部品雛形に記述さ れているため、ある部品雛形が実体化できるのは特定の納まり方す る部品のみである。図 2 に示すようなバリエーションの土台を三次 元モデル化しょうとすると、部品両端の継手の種別と上木側か下木 側かを扱うため雛形は三種類必要となる。雛形内部の仕組みは単純 であるが、求められる部品雊形の総数は多くなることがわかる。なお、 五重塔のアーカイブ化研究ではこの手法を採った。

納まり方をパラメトリックに扱う雛形を記述する場合は、ある部 品がどのような継手であるかはパラメータの操作により表現する注 2 ハンパラメトリックな手法による雛形と比較して、柔軟性のある雛 形であるといえる。部品雛形の内部の仕組みは複雑になるが、蟻継ぎ の土台も鎌継ぎの土台も、同じ雛形から実体化することができ、図 2 に示すバリエーションは一種類の雛形から表現できる。

これら二つの手法では、納まり方の記録の仕方にも違いがある。 ンパラメトリックな手法では、部品の納まり方はそれの属する部品 雛形内部に記述されており、パラメトリックな手法では部品のパラ メータとして納まり方が記録されている。例えば三次元モデル内の 鎌継ぎの個数の積算といった処理を考えると、後者ではパラメータ の走査により積算が可能であり、明快な記録手法であるといえる。納 まりを有する部品の雛形においては、納まりをパラメトリックに扱 う仕組みのほうが部品雛形を効率的に使いまわすことができ、また、 納まりの記録といった観点からも合理的であることがわかる。

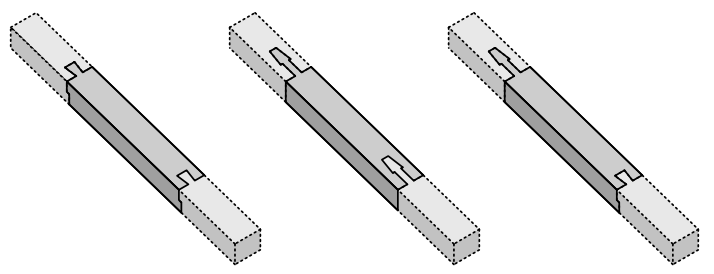

図 2：土台のバリエーション例

\section{2. 部品雛形での納まりの形状表現}

納まりをパラメトリックに扱う手法において、その部品雛形内部 での納まり形状の表現を行う仕組みを図 3 に示寸。ここでは、大工 職人の加工を模したソリッド演算（減算）処理と、そのための形状を 生成する納まりの雛形について述べる。

納まりを有する部品は、大工職人により、木材（母材）の切断、刻 みといった加工が行われることで制作される。本研究では、こういっ た大工職人の加工を模し、納まりの形状は、上木側、下木側ともに、 部品雛形内部において、母材から加工により 久如する部分をソリッ ド減算し表現する手順を採る。ソリッド減算に用いる久落部分を加 工形状と呼ぶことにすると、三次元モデルとして表現したい部品形
状は「(母材）－（加工形状）」と整理できる。大工職人による加工と の対応をさせることで、伝統木造構法の知識を表現するという観点 にも整合しており、合理的である。

部品雛形においては、パラメトリックに納まりを表現するために、 公開変数として、任意数の納まり種別と加工形状を受け取る仕組み が必要であることがわかる。また、部品雛形内部では、形状表現のた めに、「(母材）- (加工形状)」のソリッド減算を行う仕組みが求め られると整理できる。

なお、一般に取り合いや接合の表現では部品と部品のソリッド減 算注 3 を行う方法が用いられている。前出の土台の例でいえば、上木 側の継手のみを形状化しておき、下木側については、「(下木側 $)$ - (上 木側)」を行うという方法である。本研究でアーカイブ化のフロント エンドとして利用している ArchiCAD 17 注 4 でも、部品に紐付けら れた勝ち負けの優先度により、部品が干渉した際に、優先度の低い部 品が切り欠かれるといった、取り合い表現を自動的に行う仕組みが 用意されている。しかしながら、この仕組みを納まりの表現に用いる と、形状化された下木側の納まりが、上木側の部品のどの納まりによ るものかが扱えないという問題がある。また、ソリッド演算による手 法では表現しにくい納まりも多い。例えば、図 4 に示すような柱に 貫が貫通して納まる場合では、通常、柱にあける貫穴は貫の成より、 楔の分大きなものになり単純な「(柱) - (貫)」では表現できない。 解決策として、例えば貫穴をあけるためのダミー部品を新たに配置 するといった手法も考えられるが、実在しない部品が三次元モデル 上に配置されるため、管理が煩雑となってしまう。

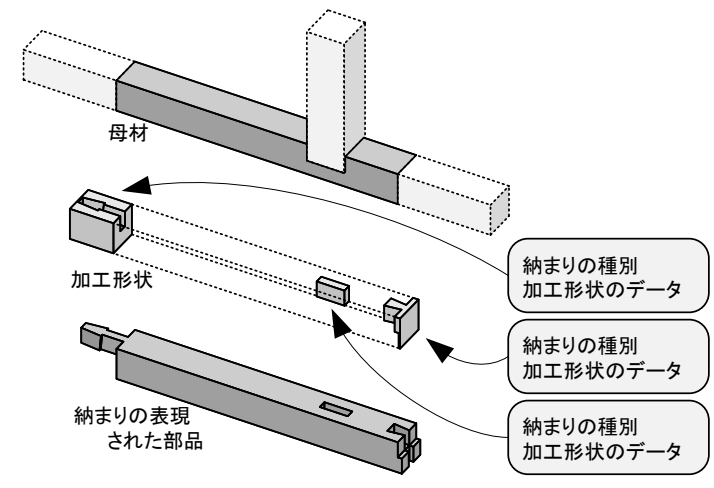

図 3：納まりを表現するための部品雛形

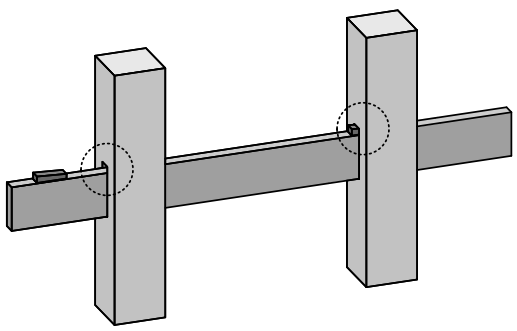

図 4： 柱と貫の納まり

\section{3. 納まりに関する手続きのプログラム言語による記述}

以上の考察を踏まえ、部品と部品が納まりを形成する際の手続き を、納まりを形成する部品の幅、成および相対的な位置関係 (姿勢) から、上木、下木それぞれの加工形状を生成する手続きであると整理 する。この手続きについて $\mathrm{C} / \mathrm{C}++$ 言語を用いて記述を行い、納まり 
雛形をクラスとして定義する。加工形状を生成する手続きは納まり の種別毎に異なる。納まりの種別毎の設計法をモデル化し、パラメト リックに加工形状が生成できるよう記述し、納まり種別毎に雛形を 用意するが、後述する納まりのパターンが同じものには共通の処理 も多いことから、クラスの派生を行い、構法の知識表現としての見通 しの良さに配慮する。

三次元モデル化に際して、納まり雛形を用い納まりの表現を行お うとすると、納まりパターンの判定 (A)、加工形状の基準となる座 標系（納まり座標系）の計算 (B)、納まり雛形の実体化による加工形 状の生成（C）という手順になる。（A）（B）についても、C/C++言語 により記述を行い、納まりの形成システムとして実装した。当システ ムにおける処理の流れを、横材と横材による渡り思での納まりが表 現されるまでを例に、図 5、(1)〜(6)に示す。

(1) 納まりを形成する部品それぞれの、部品種別注 5、始点、終点の 三次元座標、幅、成、芯線注 6 を軸とする回転角をシステムに送 信する。

(2) 納まりのパターンの判定（A）を行う。ここでは芯線の交点注7 と部品の始点、終点の位置関係からパターンを判定する。シス テムでは、(二つの横材が) 納まりを形成する際のパターンを図 6 に示寸 4 パターンに整理した。納まりのパターンに応じて適 用可能な納まり種別のリストを作成する。適用可能な納まり種 別については、納まりのパターンの他に、(ここでは簡単のため 単に横材としているが）部品の種別、あるいは三次元モデル化 の対象とする建築の建立年代や様式などの情報をもとに列挙 することも考えられる。

(3)二つの部品の位置関係によっては上木側となる部品と下木側 となる部品が自動的に決まる場合もあるが、そうでない場合は 操作者に指定を求める。また、(2)で作成した納まりのリストを 表示し、適用寸る納まりの指定を求める。

(4) 加工形状の基準となる座標系(納まり座標系)の算出を行う(B)。 まず、それぞれの部品の始点、終点および回転角から部品の姿 勢を同次 (座標) 変換行列注 8 として求める。この同次変換行列 は各部品のローカル座標系を意味するものである。次に、各部 品のローカル座標系を芯線の交点にオフセットしたものを納 まり座標系とし同次変換行列を算出する。加えて、納まり座標 系の向きを、納まり雛形として記述した際の向きとあうよう必 要に応じて調整する。図 5 に示した X 型の納まりパターンに おいては、納まり雛形の向きにあうよう下木側の納まり座標系 をZ 軸中心に回転を加えている。

（5)納まり雛形を実体化し加工形状を生成（C）する。納まり雛形 では、各部品の幅成、納まり座標系への同次変換行列をもとに、 上木側、下木側それぞれの加工形状の生成が行われる。生成し た加工形状は、部品に返した際に当部品のローカル座標系にお いて適切な姿勢になる必要がある。(4)にて求めた二つの同次変 換行列をもとに変換行列を算出し乗じておく。

(6)上木側、下木側の部品それぞれに納まりの種別と加工形状注 9 が パラメータとして返される。

以上の処理の結果、部品 (雛形) の内部で「(母材) - (加工形状)」 のソリッド減算が行われ、渡り思での納まりが三次元モデル上で表 現される。横材と縦材についてもシステムに手続きを記述した。横材
同士の場合と処理の流れは同様であるが、納まりのパターン整理が 横材同士の場合とは異なる。

また、図 5 はフロントエンドである ArchiCAD の機能と、納まり 形成システムの機能とを分けて図化してある。(3)ように途中で操 作者に納まりの種別や上木側部品の指定を求める際に ArchiCAD の ユーザインタフェースを借用しているが、(2)、(4)、(5)、(6)といった納 まりを形成する際の手続きは、特定の $\mathrm{CAD}$ に依存しない独立したシ ステムとして実装を行った。三次元モデルの形状表現についても、

ArchiCAD の機能である GDLによる部品雛形では、「（母材）－（加 工形状)」のソリッド減算のみを行っている。

本システムの機能を端的に述べると、納まりを形成する部品の諸 情報（幅成および位置、姿勢）に加え、納まり種別と上木側となる部 品の指定を入力すると、その納まりを形成するための加工形状を返 す機能である、と整理できる。これは、大工職人が部品と部品の取り 合いを考える際に、納まりを設計し加工に向けた墨付けを行う工程 と対応するものであるということもできる。汎用性のある $\mathrm{C} / \mathrm{C}++$ 言 語で記述できており、他の三次元 $\mathrm{CAD}$ での利用が可能であると見込 んでいる。

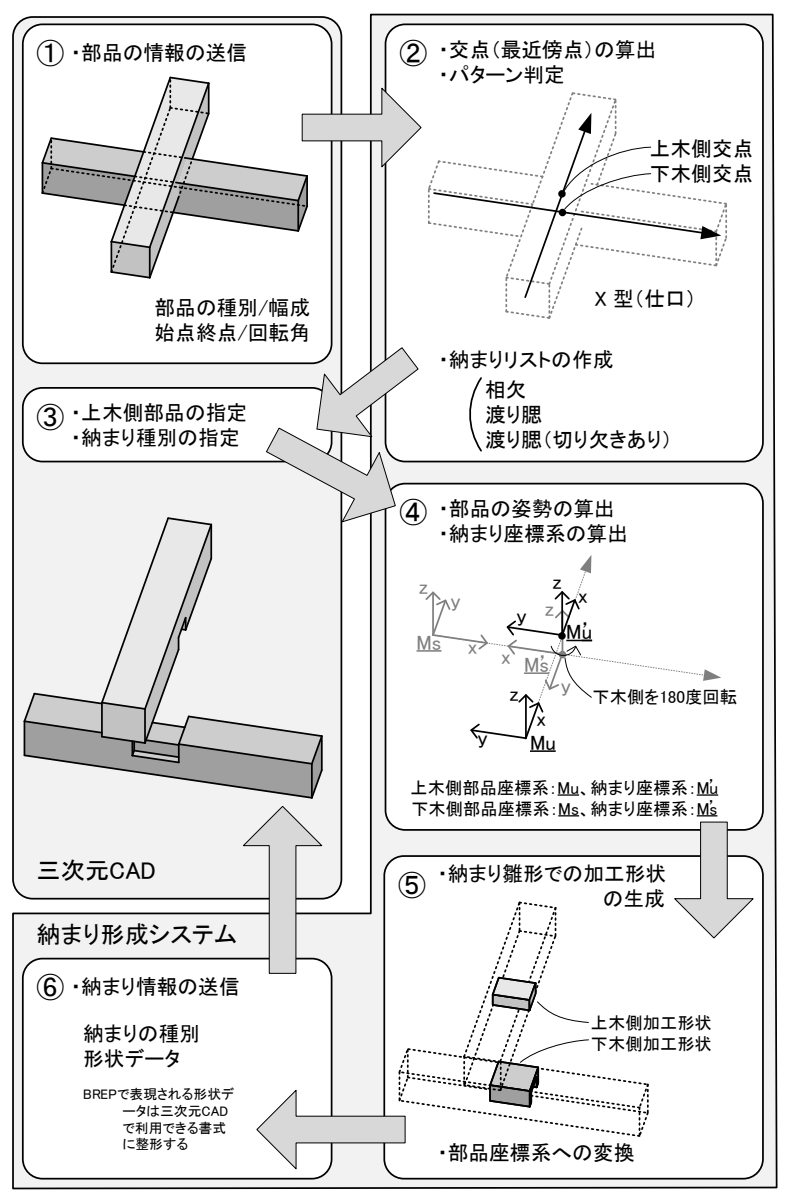

図 5: 納まりの形成システムでの処理の流れ
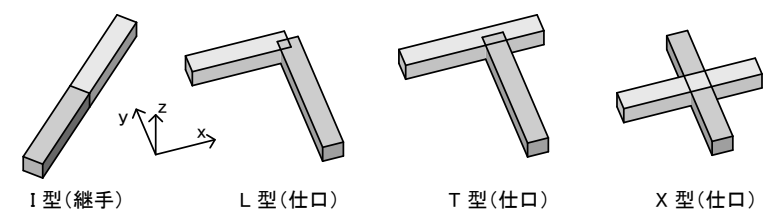

T 型(仕口)

図 6: 納まりのパターン下段 : 横材と縦材 


\section{1. 姫路城大天守の三次元モデル化}

姫路城大天守二重屋根部および三重南東部の三次元モデル化にお いて、本システムの試作を行い、フィードバックを重ねた。主として 軸部に多用される納まりについて、納まりの雛形を記述しシステム への組み込みを行ったが、軸部の大半の部品の納まりに本システム を適用することができた。部品雛形や納め方の管理に問題が生じる こともなかった。また、納まりの雛形において、下木側となる加工形 状をオフセットさせることで、納まりのクリアランスを表現する実 装も行った（図 7)。三次元プリンタでの出力を前提としたクリアラ ンスであり大工職人の技巧を忠実に表現したものではないが、出力 や組み上げの際に逐一調整を行う必要もなくなり、歪みの少ない模 型ができたと考えている。図 8 に三次元モデルの分解図と、三次元 モデルおよび三次元プリンタにより出力したスケール模型（1/30）を 示す。

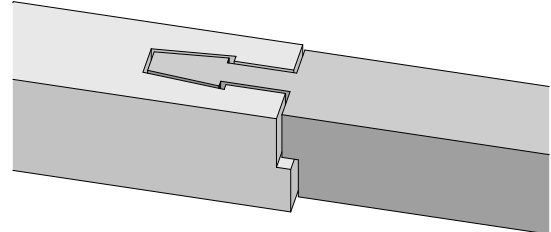

図 7：模型化に向けたクリアランスの表現注 10

\section{4. まとめ}

伝統木造構法に特徵的な継手仕口による納まりに関して、その手 続きをプログラム言語による記述を行い、知識として表現すること を試行し、以下について報告した。

納まりを有する部品の雛形について考察を行い、納まりの表現の ために設定する公開変数と大工職人の加工に準えソリッド減算によ り形状表現を行う仕組みを示した。納め方に関する手続きについて は、手続きを、納まりのパターンの判定、加工の記述となる座標系の 算出、納まり雛形による加工形状の生成と整理し、実装した納まりの 形成システムの処理手順を示した。システムの試作と平行して行わ れた姫路城大天守の三次元モデルについても報告した。

本稿では納まりの知識のうち形状の表し方や形成手続きに着目し 報告を行ったが、引き続き納まり雛形の記述を進めつつ、その体系化 や知識ベース化といった展開も試みていきたい。

\section{謝辞}

姫路城大天守の三次元モデル化にあたり、調查協力および資料提 供を受けた姫路市立城郭研究室に感謝する。また、本研究は、科学研 究費補助金 (25420626)、特別研究員奨励費 (24005874) の助成に よって行われたものである。

注釈

注 1： 部品雛形の記述には ArchiCAD (注 5 参照)に付属のオブジェク 卜記述のためのプログラム言語 GDL（Geometric Description Language）を利用している。

注 2： 具体的に操作すべきパラメータや、こういった操作を実現する部 品雛形の仕組みについては、次節に記した。

注 3：ここでのソリッド演算は、部品と部品のソリッド演算である。本 研究で納まり形状に用いると記したソリッド演算は、部品雛形内 部で行うものであり、納まり種別の記録や形状表現上の問題とは 関連がない。

注 4： Graphisoft 社開発の建築用三次元 CAD である。

注5：ここでは、部品の種別は単に「横材」としている。今後、土台や 長押といった細分化した種別を扱うことを予定している。

注6：始点と終点を結ぶ線を芯線と呼んでいる。また、始点と終点の高 さ方向の位置は便宜上断面の中心に置いている。

注 7：三次元空間における線分であるので、交差しないことも多いが、 最近傍点を交点として扱っている。故に、上木側の交点と下木側 の交点の二つの交点を使い処理を進めていく。

注 8：同次変換行列は、並進（位置）と回転を表す行列であり、三次元 モデル（空間）においては $4 \times 4$ の行列となる。コンピュータグラ フィクスやロボットの分野でよく用いられる。

注 9：加工形状の雛形の記述に $\mathrm{C} / \mathrm{C}++$ 言語を用いた場合、雛形内部では BREP による形状を生成されるよう記述しているが、フロントエ ンドである ArchiCAD（の部品）に返す際に GDL の書式に書き 換えたものを出力している。また、BREP とは頂点、稜線、によ る境界表現（Boundary Representation）で形状を表す手法であ る。三次元 CAD 内部での形状表現に一般的に用いられている。

注 10 ：幅成の異なる部品での腰掛け鎌継ぎを例示した。また、図化のた めクリアランスを大きく設計している。

\section{参考文献}

1）加戸啓太、平沢岳人：伝統木造建築物のデジタルアーカイブ化に 抢ける部品雛形と部品に関する研究、日本建築学会計画系論文集、 第 76 巻 第 662 号、pp.877-886、2011.4

2）富樫新三: 大工宮ひな形一一間社から扯殿・鳥居まで、理工学社、 2000

3） 木内修：現代棟梁の設計術一五意達者への道、新築社、2007

4）富樫新三：木造建築の継手と仕口、オーム社、2010

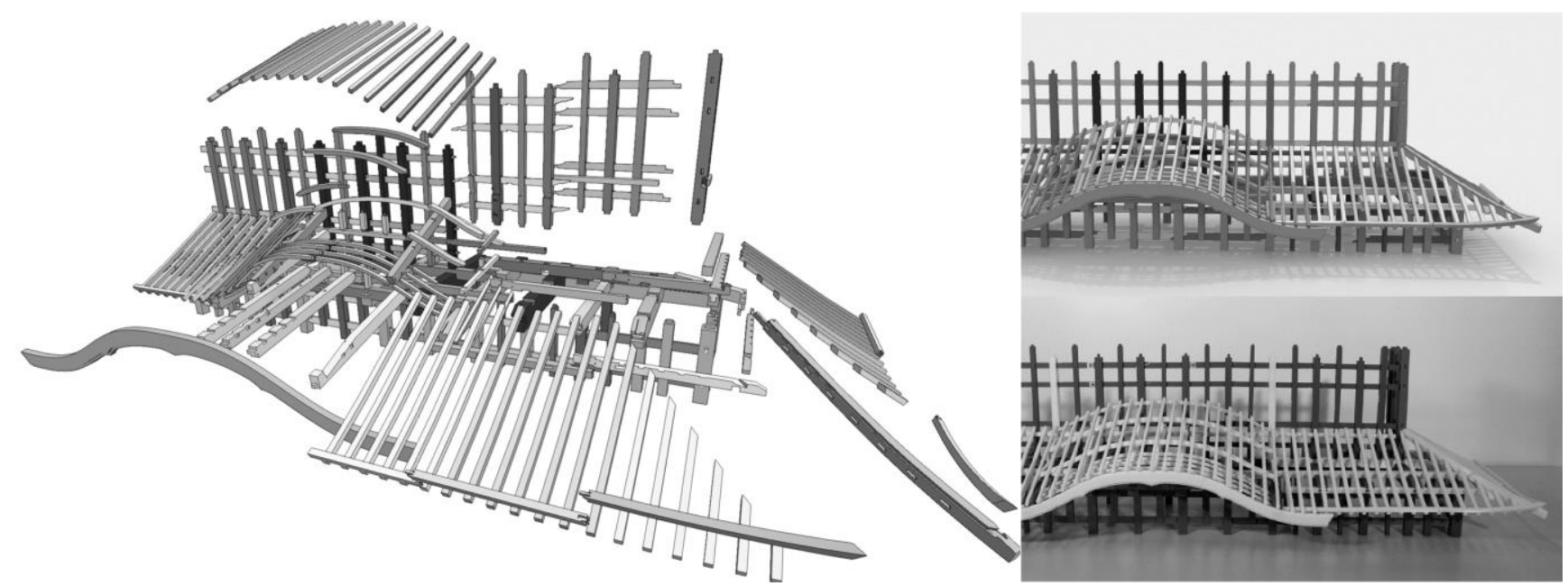

